\title{
Development of Reading Comprehension Ability Assessment for Students
}

\author{
Dalman $^{1}$, Mardiana $^{2}$, Hesti $^{3}$, Ahmad Luviadi $^{4}$, Roni Sulistiyono ${ }^{5}$ \\ \{dalman.bangka@gmail.com ${ }^{1}$ \} \\ Universitas Muhammadiyah Lampung, Lampung, Indonesia ${ }^{1,2,3,5}$ \\ Universitas Ahmad Dahlan, Yogyakarta, Indonesia ${ }^{4}$
}

\begin{abstract}
Reading Skills courses for students in Higher Education, especially in the Indonesian Language Study Program at the University of Muhammadiyah Lampung are not easy to achieve in learning indicators. The measuring instrument used for the assessment is the manual assessment and it is not effective yet. The alternative to seeing the achievement of language learning outcomes is to use the right measuring instrument, namely the assessment instrument (assessment) of reading comprehension. This assessment is developed based on the concept / theory of reading comprehension. The objective of this study is: to develop an assessment instrument to measure students' reading comprehension skills for Indonesian Language Education students. The data collecting method is done through the Borg \& Gall development method with five stages, 1) research and information collecting, 2) planning, 3) develop preliminary form of product, 4) preliminary field testing, and 5) final product. This research has limitations, namely the product in the form of an instrument as a new assessment tool until the validity test stage and the research can be developed again to be broader and more perfect.
\end{abstract}

Keywords: Assessment Development, Reading Comprehension, Student

\section{Introduction}

Literacy as one of the Government programs is an effort of all parties to make it happen, including in Higher Education. Language competence in the achievement of Indonesian language learning in tertiary institutions is an absolute thing, this competence really supports the provision of students to be able to apply language knowledge correctly and appropriately in the community as a medium or vehicle for appreciating the knowledge that has been obtained. Language in which there is an element of reading by various methods certainly requires accuracy in its assessment.

One of the obstacles in the assessment for reading comprehension is that the instruments are not in accordance with the desired competency attainment. The assessment, according to Mardapi [10], is the efforts to improve the quality of education can be pursued through improving the quality of learning and the quality of the assessment system. Appropriate assessment instruments are 
needed to measure the accuracy of learning in this particular case for reading comprehension.

This study aimed to improve the assessment system related to assessment instruments, considering that assessment is very important in learning. The urgency of this research is to improve the reading comprehension instrument, which so far has been the same as the assessment of reading skills in general. It is hoped that the improvement of the instrument for assessing the ability to read comprehension is expected to be the right measurement tool for all Indonesian Language Education Study Programs in all universities and especially in the Indonesian Language Study Program at the University of Muhammadiyah Lampung.

\subsection{Assessment}

Assessment is a measure activity related to numbers objectively, according to Allen \& Yen [3] defining measurement as assigning numbers in a systematic way to express individual circumstances.

Some assessments are measures for the success of a learning program or learning indicators in a course, then the assessment should be adjusted to the material discussed or in accordance with the standards applied [18]. The importance of assessment instruments that are in accordance with the indicators or concepts makes the scoring system more valid and reliable.

\subsection{Language}

Language is a spoken symbol [16]. The language component in which there is a series of words in this case is studied in a science called morphology [13], [17]. The relationship between words at the morphological level is part of a broader knowledge, namely syntax. Language acquisition through several stages, namely listening, speaking, reading, and writing [12].

The relationship in the language unity between listening, speaking, reading, and writing is one unit. The relationship between reading and writing is very close, in writing activities, authors use written language and can make the position of the writer as a reader and writer and reader as a writer [8] [9]. Reading as one of the courses certainly has certain points in the achievement of understanding the reading content, not only limited to reading skills that are owned but must be able to make other contributions that support reading comprehension as an optimal activity, this can also be done by using a variety of learning methods [1] [4]. The method used by the lecturer is also very helpful in achieving maximum results regarding reading comprehension. 
Furthermore, reading comprehension is a stage in reading or can be called also advanced reading [7]. In the Indonesian Language Education (PBI) study program, reading comprehension is included in the field of reading skills, of course the assessment system does not yet have a special instrument. There are several studies that are relevant to the material or assessment of reading comprehension [14] [15]. Some of the relevant research above, discuss methods or techniques of learning to read and discuss how important assessment is for reading comprehension for learning English. The renewal of the Assessment product is an assessment instrument used for the specific reading skills course of Reading Comprehension Skills.

\section{Method}

This research is a research development using the $R \& D$ method, three stages are used namely the first is the stage of pre-development, the second is stage of development, and the third is the final stage. The three stages use five steps of R\&D development. These stages can be seen in Figure 1.

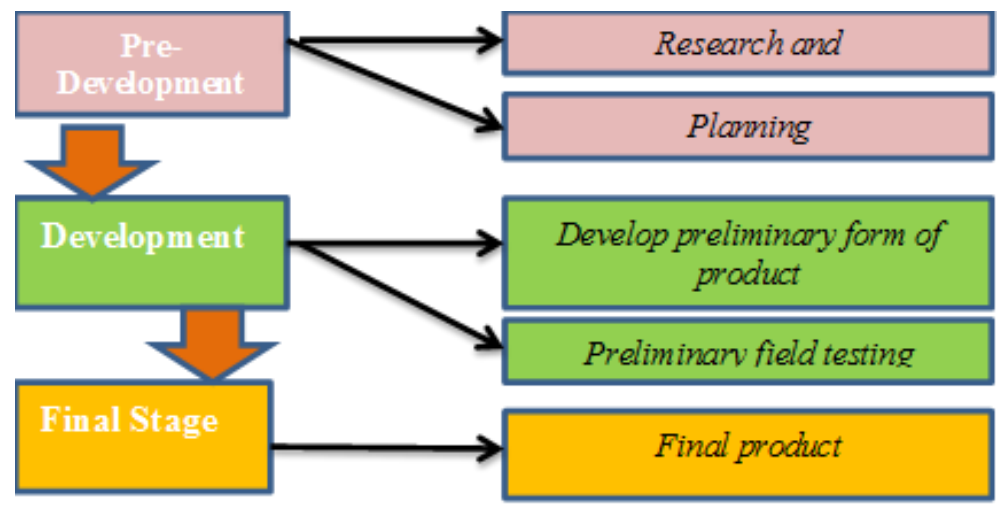

Fig. 1. Assessment development stage

First: Pre-Development; 1. Research and Information Collecting: Conducting preliminary research and collecting data about assessment instruments that already exist and are used in assessing students' reading skills, then a literature review and relevant research studies are conducted; 2. Planning: Making plans based on literature reviews and preliminary research, it is necessary to have an assessment instrument. Second: Development Stage; 3 . Develop preliminary form of product: Analyze concepts / theories and journal reading comprehension skills, based on this analysis, an assessment instrument design is obtained; 4. Preliminary field testing, at this stage expert and 
practitioner validation is held involving three experts as experts. Third: Final Stage; 5. Final product; The resulting instrument can be used as an assessment for students in the Indonesian language education study program.

Furthermore, the resulting assessment instrument was tested for validity using Aiken's content validity test. The appraiser (Rater) consists of three experts in the field of Indonesian. Aiken's formula calculates content validity based on the results of expert assessments [2] [11].

$$
V=\Sigma s /[n(c-1)]
$$

Where $\mathrm{s}=\mathrm{r}-\mathrm{lo} ; \mathrm{lo}=$ the lowest validity score $\mathrm{c}=$ the highest validity score; $\mathrm{r}=$ the score given by the assessor. Furthermore, the categories are used as in Table 1.

Table 1. Category

\begin{tabular}{cl}
\hline Score & Category \\
\hline 1 & Irrelevant \\
2 & Lack of Relevant \\
3 & Quite Relevant \\
4 & Very Relevant \\
\hline
\end{tabular}

The validation index used is: less than 0,4 , the validity is low, between $0,4-$ 0,8 the validity is moderate, and if it is more than 0,8 , the validity is high [11]. The criteria used by the rater to assess the suitability of indicators and items can be presented in Table 2 .

Table 2. Conformity criteria

\begin{tabular}{cl}
\hline Number & Criteria \\
\hline 1 & Language \\
2 & Theory \\
3 & Construction \\
4 & Objectivity \\
5 & Systematics \\
\hline
\end{tabular}

\section{Results and Discussion}

Reading comprehension has six indicators based on literature review, as presented in Table 3. 
Table 3. Indicator

\begin{tabular}{lll}
\hline Number & Indicator & Item \\
\hline 1 & The stages of completing further reading & 1 \\
2 & Understand the content of the reading & 2 \\
3 & Interpret the content of the reading & 3 \\
4 & Analyze the content of the reading & 4 \\
5 & Examine the content of the text & 5 \\
6 & Bring up new posts & 6 \\
\hline
\end{tabular}

Based on the resulting assessment instrument, there are six item questions with five assessment aspects. The assessment was carried out to see the compatibility of the six question items with the five aspects assessed by the three rater, namely Language, Materials, Construction, Objectivity, and Systematics. The results of the analysis using Aiken's can be seen in Table 4.

Table 4. Expert Assessment

\begin{tabular}{|c|c|c|c|c|c|c|}
\hline Criteria & No & 1 & 2 & 3 & Total & AIKEN \\
\hline \multirow[t]{12}{*}{ Language } & 1 & 3 & 3 & 3 & & \\
\hline & $\mathrm{s}$ & 2 & 2 & 2 & 6 & 1 \\
\hline & 2 & 3 & 4 & 4 & & \\
\hline & s & 2 & 3 & 3 & 8 & 1 \\
\hline & 3 & 4 & 4 & 4 & & \\
\hline & $\mathrm{s}$ & 3 & 3 & 3 & 9 & 1 \\
\hline & 4 & 3 & 4 & 4 & & \\
\hline & $\mathrm{s}$ & 2 & 3 & 3 & 8 & 1 \\
\hline & 5 & 3 & 3 & 3 & & \\
\hline & $\mathrm{s}$ & 2 & 2 & 2 & 6 & 1 \\
\hline & 6 & 4 & 4 & 4 & & \\
\hline & $\mathrm{s}$ & 3 & 3 & 3 & 9 & 1 \\
\hline \multirow[t]{14}{*}{ Theory } & 7 & 4 & 4 & 4 & & \\
\hline & $\mathrm{s}$ & 3 & 3 & 3 & 9 & 1 \\
\hline & 8 & 4 & 4 & 4 & & \\
\hline & $\mathrm{s}$ & 3 & 3 & 3 & 9 & 1 \\
\hline & 9 & 3 & 4 & 4 & & \\
\hline & $\mathrm{s}$ & 2 & 3 & 3 & 8 & 1 \\
\hline & 10 & 3 & 4 & 3 & & \\
\hline & $\mathrm{s}$ & 2 & 3 & 2 & 7 & 1 \\
\hline & 11 & 4 & 4 & 4 & & \\
\hline & $\mathrm{s}$ & 3 & 3 & 3 & 9 & 1 \\
\hline & 12 & 4 & 3 & 4 & & \\
\hline & $\mathrm{s}$ & 3 & 2 & 3 & 8 & 0,89 \\
\hline & 13 & 4 & 4 & 4 & & \\
\hline & $\mathrm{s}$ & 3 & 3 & 3 & 9 & 1 \\
\hline \multirow[t]{2}{*}{ Objectivity } & & 3 & 4 & 4 & & \\
\hline & $\mathrm{s}$ & 2 & 3 & 3 & 8 & 0,89 \\
\hline \multirow[t]{2}{*}{ Systematics } & & 3 & 4 & 4 & & \\
\hline & $\mathrm{s}$ & 2 & 3 & 3 & 8 & 0,89 \\
\hline \multirow[t]{4}{*}{ Construction } & 14 & 4 & 4 & 4 & & \\
\hline & $\mathrm{s}$ & 3 & 3 & 3 & 9 & 1 \\
\hline & 15 & 3 & 4 & 4 & & \\
\hline & $\mathrm{s}$ & 2 & 3 & 3 & 8 & 1 \\
\hline
\end{tabular}




\begin{tabular}{cccccc}
16 & 4 & 4 & 3 & & \\
$\mathrm{~s}$ & 3 & 3 & 2 & 8 & 0,89 \\
\hline 17 & 4 & 4 & 4 & & \\
$\mathrm{~s}$ & 3 & 3 & 3 & 9 & 1 \\
\hline 18 & 3 & 4 & 4 & & \\
$\mathrm{~s}$ & 2 & 3 & 3 & 8 & 0,89 \\
\hline
\end{tabular}

Based on the data presented in Table 4, it is found that all items are valid and are in the very relevant category with the Aiken index greater than 0.8.

\section{Conclusion}

The assessment developed is very useful for assessing language learning comprehension for Indonesian study program students. The instrument developed consists of six indicators with six items, and its relevance is seen with five criteria. The criteria seen from the suitability of indicators and items are language, material, construction, objectivity, and systematization. Content validation was assessed by three assessors (rater) with very relevant assessment results, shown by index results $>0.8$.

\section{References}

[1] Aan Khasanah\&Isah Cahyani. (2016). Peningkatan Kemampuan Membaca Pemahaman dengan Strategi QAR. Jurnal Pedagogik Pendidikan, Jilid 4 Nomor 2, Juli 2016. Hal. 161-175.

[2] Aiken LR. (1985). Three Coefficients for Analyzing the Reliability and Validity of Ratings. Educational and Psychological Measurement, 45: 131. DOI: 10.1177/0013164485451012.

[3] Allen, M.J \& Yan, W.M. (1979).Introduction to measurement theory. California: Brooks/Cole Publishing Company.

[4] Ani S, Jenny I \& Matsuri. (2017). Peningkatan Keterampilan Membaca Pemahaman melalui Strategi QAR (Question Answer Relationships). Jurnal Didaktika Dwija Indria. ISSN: 2337-8786.

[5] Borg, W. R. \& Gall, M. D. (1983). Educational research: an introduction. New York: Longman.

[6] Creswell, J. W. (2010). Research design pendekatan kualitatif, kuantitatif dan mixed. Yogyakarta: Pustaka Pelajar.

[7] Dalman. (2014). Keterampilan Membaca. Jakarta: PT. Rajagrafindo Persada.

[8] ------. (2015). Keterampilan Menulis. Jakarta: PT. Rajagrafindo Persada.

[9] -----(2015). Penulisan Populer. Jakarta: PT. Grafindo Persada.

[10] Djemari Mardapi. (2009). Teknik penyusunan instrumen tes dan nontes. Yogyakarta: Mitra Cendekia.

[11] Heri Retnawati. (2016). Validitas Reliabilitas dan Karakteristik Butir. Parama Publishing: Yogyakarta.

[12] Iskandarwassid, Dadang Sunandar. (2011). Strategi Pembelajaran Bahasa. Bandung: Pascasarjana UPI\&PT Rosdakarya.

[13] Jensen, John T. 1990. Morphology: Word Structure in Generative Grammar. Amsterdam: John Benjamins Publishing Company.

[14] Muhafidin. (2016). Pembelajaran Membaca Pemahaman Pada Siswa. Jurnal Profesi Pendidikan dasar, Vol. 3, No.1, hal. 66-70. 
[15] Munoz Marin JH. (2009). Exploring Teachers' Practices for Assessing Reading Comprehension Abilities in English as a Foreign Language. Profile Journal Vol. 11, No. 2. ISSN: 1657-0790. Bogota, Colombia, pages 71-84.

[16] Soenjono Dardjowidjojo. (2010). Psikolinguistik, Pengantar Pemahaman Bahasa Manusia. Jakarta: Yayasan Obor Indonesia.

[17] Spencer, Andrew. (1991). Morphological Theory: An Introduction to Word Structure in Generative Grammar. Cambridge: Basil Blackwell.

[18] Polikoff, M.S, Andrew C Porter I\&John Smithson. (2011). How Well Aligned are State Assesments of Student Achievement: With State Content Standards. American Educational Research Journal, month XXXX, Vol. XX, No. X, pp.1-31 DOI: 10.3102/00283121410684. 2011 AERA. http://aerj.aera.net. 